\title{
NUTRIENT BUDGETING, ECONOMICS AND ENERGETICS OF COWPEA UNDER POTASSIUM AND PHOSPHORUS MANAGEMENT
}

\author{
V. K. Choudhary ${ }^{* 1}$ and P. Suresh Kumar ${ }^{2}$ \\ ICAR, Research Complex for North Eastern Hilly Region, Arunachal Pradesh Centre, \\ Basar-791 101, India
}

\begin{abstract}
Low availability of phosphorus $(P)$ and potassium $(K)$ in acidic soil is a major constraint for crop production. Cowpea was grown under split-plot design with three levels of $\mathrm{K}$ and $\mathrm{P}$ (viz., $100 \%, 75 \%$ and $50 \%$ of recommended dose). Green pod and stover yield was 20.9 and $16.9 \%$ higher with $100 \% \mathrm{~K}$ over $50 \% \mathrm{~K}$ application. Similarly, $100 \% \mathrm{P}$ had $20.2 \%$ higher green pod and $16.6 \%$ higher stover yield over $50 \% \mathrm{P}$. Production efficiency was found higher with $100 \% \mathrm{~K}$ and $\mathrm{P}$ (48.6 and $49.0 \mathrm{~kg} \mathrm{ha}^{-1}$ day $^{-1}$ respectively) followed by $75 \% \mathrm{~K}$. The actual gain of $\mathrm{N}$, $P$ and $K$, and balance were higher with the increase of $K$ and $P$ levels but reverse in case of gross and net return, and BCR. The energy productivity and energy use efficiency were higher on $100 \% \mathrm{~K}$ and $\mathrm{P}$. Cowpea on acid soil along with $100 \%$ recommended dose of $40 \mathrm{~kg} \mathrm{~K}$ and $60 \mathrm{~kg} \mathrm{P} \mathrm{ha}^{-1}$ showed highest yield along with soil fertility restoration as well as reduced the cost of inorganic fertilizer, higher BCR (1.89) and energy requirement.
\end{abstract}

Key words: Cowpea, economics, energy, phosphorus, potassium

\section{INTRODUCTION}

Cowpea (Vigna unguiculata L.) is an important grain legume in rainfed regions and marginal areas of the tropics and subtropics. It is particularly important in India because this crop can be used as pulse, vegetable and fodder. Cowpea is grown by most farmers due to its short growing cycle. The grain is a good source of human protein, while the haulms are valuable source of livestock protein (Mpepereki et al., 2000). Apart from these, the cowpea reduces the soil erosion, enriches the soil by atmospheric nitrogen $(\mathrm{N})$-fixation and reduces the weed growth by smothering effect, and therefore, it is considered as important legume cum vegetable crop. Cowpea can fix more than $50 \%$ of its $\mathrm{N}$ from $\mathrm{N}_{2}$-fixation (Khan et al., 2002).

\footnotetext{
${ }^{*}$ Corresponding author email: ind_vc@rediffmail.com

${ }^{1}$ Scientist (Agronomy), National Institute of Biotic Stress Management, Raipur- 493225

${ }^{2}$ Senior Scientist (Horticulture), National Institute of Abiotic Stress Management, Baramati- 413115
}

Received: 14.05.2013 
Crop productivity on more than $40 \%$ of earth's arable land is limited by poor plant availability of P (Vance, 2001). The generally poor food situation in Eastern Himalayan Region (EHR) is related to the low availability of $\mathrm{P}$ in the soil. Moderate applications of $\mathrm{P}$ fertilizer often have only marginal effect on yields due to $\mathrm{P}$ fixation by Iron (Fe) and Al-oxides in the soils (Sample et al., 1980). Most of the soil-P is bound in sparingly soluble $\mathrm{P}$ pools and not immediately available to support plant growth. The low availability of soil phosphorus may limit $\mathrm{N}_{2}$-fixation and also uptake of K. Pulse crop required higher amount of $\mathrm{P}$ to develop their root system. Positive effects of grain legumes on yields of cereals grown in rotation may also be due to enhanced P-availability through secretion of enzymes and acids in the legume rhizosphere (Schlecht et al., 2006). The functions of potassium in plant-water relations, energy and enzyme synthesis and tolerance against diseases are well documented. Application of $\mathrm{P}$ and $\mathrm{K}$ fertilizer is essential for optimal crop yields when soils are deficient with then. The agronomic efficiency of inorganic P fertilizers has been reported to be only $10-25 \%$ within the first year of application, as a large portion of applied fertilizer $\mathrm{P}$ is fixed by soil and therefore become unavailable to plant (Thierry, 2008). Cowpea is an important leguminous crop, but the crop is grown under poor soil with or without chemical inputs, therefore, the productivity is very low. An attempt was therefore, required to estimate the nutritional need of the crop to harvest higher yield, nutrient budgeting, economics and energy involvement in production.

\section{MATERIALS AND METHODS}

\section{Climatic condition and experimental site}

A field experiment was carried out at the experimental farm of ICAR Research Complex for NEH Region, Arunachal Pradesh Centre, Basar, located at West Siang District of Arunachal Pradesh, India during 2009 and 2010. Experimental site was at $27^{\circ} 95^{\prime} \mathrm{N}$ latitude, $94^{\circ} 76^{\prime} \mathrm{E}$ longitude with $660 \mathrm{~m}$ above MSL and falls under humid sub tropical climate. The daily temperature during the study period varied widely between minimum of $20^{\circ} \mathrm{C}$ and maximum of $35^{\circ} \mathrm{C}$, received average rainfall of 1300 $\mathrm{mm}$ from March to June. The physical and chemical properties of the soils are silty loam in texture, acidic in reaction $(\mathrm{pH} \mathrm{5.3),} \mathrm{high} \mathrm{in} \mathrm{organic} \mathrm{carbon} \mathrm{(Walkaley} \mathrm{and}$ Black, $1.50 \mathrm{~g} \mathrm{~kg}^{-1}$ ), low in available $\mathrm{N}$ (alkaline permanganate $\mathrm{N}, 205.6 \mathrm{~kg} \mathrm{ha}^{-1}$ ), low in available phosphorus (Bray P, $8.3 \mathrm{~kg} \mathrm{ha}^{-1}$ ) and medium in available $\mathrm{K}$ (Neutral normal ammonium acetate $\left.\mathrm{K}, 260 \mathrm{~kg} \mathrm{ha}^{-1}\right)$.

\section{Treatment details}

The experiment was laid out in split-plot design with three replications. Main plots were subjected to potassium with three levels (viz. 100, 75 and 50\% of recommended dose (RD)) and sub-plots were subjected to phosphorus with three levels (viz. 100, 75 and $50 \%$ of RD) i.e. 40,30 and $20 \mathrm{~kg} \mathrm{~K}$ and 60,45 and $30 \mathrm{~kg} \mathrm{P}$ $\mathrm{ha}^{-1}$. The recommended dose of fertilizers $\left(25: 60: 40 \mathrm{~kg} \mathrm{NPK} \mathrm{ha}^{-1}\right)$ was applied in the 
form of urea, single super phosphate and muriate of potash, respectively. Five tones of well decomposed manure were applied at final land preparation and all the fertilizer as per treatments were applied prior to sowing. Seeds were sown with spacing of $45 \mathrm{~cm} \times 20 \mathrm{~cm}$ and all other cultural operations were done as per recommendation.

\section{Observations on crop and soil}

Green pod and stover yield was recorded from the net plot area of $\left(3.0 \mathrm{~m}^{2}\right)$. Production efficiency was calculated by dividing green pod yield by 85 days duration of cowpea. Soil samples were collected before and after the experiment and plant samples were collected at the time of final harvest for chemical analysis. The contents of $\mathrm{N}, \mathrm{P}$ and $\mathrm{K}$ in the plant were analyzed by standard procedure and the total uptake of nutrients by plants was calculated from their contents in the plants multiplied by dry matter yield and expressed in $\mathrm{kg} \mathrm{ha}^{-1}$. N, P and $\mathrm{K}$ use efficiency was calculated by nutrient uptake by crop per hectare to the nutrient applied to the individuals.

\section{Energetic parameters}

Energy input and output was calculated using energy equivalents as suggested by Devasanapathy et al. (2009). Energy use efficiency ( $\mathrm{kg}$ pod $\mathrm{MJ}^{-1}$ and $\mathrm{kg}$ dry matter $\mathrm{MJ}^{-1}$ ) was calculated by dividing green pod yield $(\mathrm{kg})$ by total input energy $(\mathrm{MJ})$ and total dry matter produced $(\mathrm{kg})$ by total input energy $(\mathrm{MJ})$. The details of energy parameters and their estimation are given in table 1.

Table 1: Energy parameters and their estimation

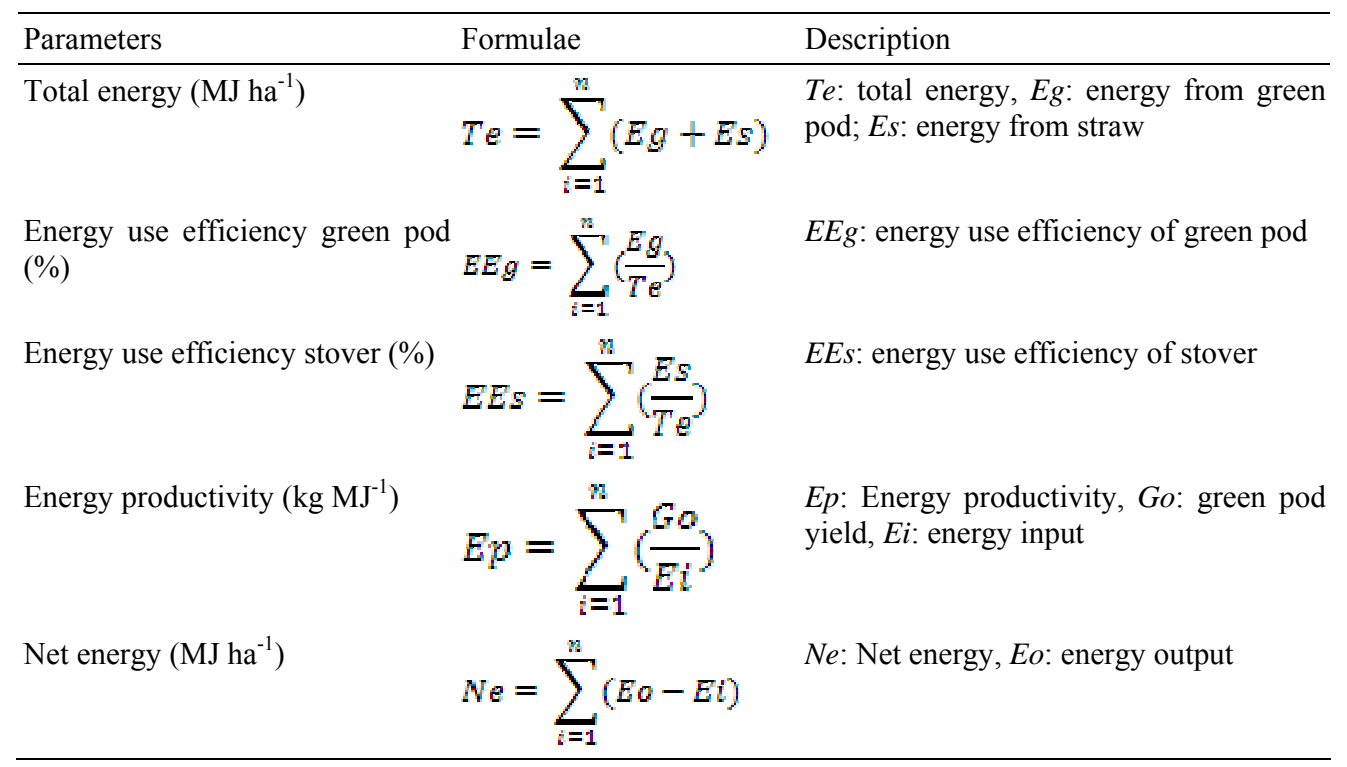




\section{Economic and statistical analysis}

Economic analysis was worked out as per prevailing market prices of the inputs and produce. The price $\left(₹ \mathrm{t}^{-1}\right)$ of cowpea pod and stover were $₹ 8000$ and 500 respectively [USD $1(\$)=₹ 48.0$ ] constant for both the years. The analysis of variance of the data was carried out by using SAS 9.2 software. Treatment mean differences were separated by the least significant difference (LSD) test at 0.05 probability level.

\section{RESULTS AND DISCUSSION}

\section{Total dry matter and yield}

Total dry matter (TDM) content significantly varied with $\mathrm{K}$ and $\mathrm{P}$ levels in cowpea (Table 2). TDM was highest with the application of $\mathrm{K}$ with $100 \%$ of recommendation. There was trend to decrease TDM with the decrease of K levels. Similar trend was followed in both the years. Similarly, 100\% P had highest TDM in both the years. This is because of higher growth attributes viz. leaf number and leaf area (data not presented), which helped the plant to produce more photosynthesis and accumulated in different plant parts (Abayomi et al., 2008). Green pod and stover yields were significantly highest with $100 \% \mathrm{~K}$ which showed 20.2 and $21.5 \%$ of green pod, and 11.2 and $22.6 \%$ of stover yield for 2009 and 2010, respectively higher over 50\% K. Though, 100 and 50\% P application showed at par in 2010. Phosphorus application with $100 \% \mathrm{P}$ recorded 19.8 and $20.5 \%$ higher green pod yield and 11.5 and $19.6 \%$ higher stover yield for 2009 and 2010, respectively over 50\% P. Similar results were also observed by Neumann and George, 2009.

\section{Production efficiency}

Data presented in table 2 clearly depicts that production efficiency (PE) significant $(\mathrm{P}<0.05)$ differed with $\mathrm{K}$ and $\mathrm{P}$ levels. $\mathrm{PE}$ in $\mathrm{K}$ application with 100 and $75 \%$ showed identical in 2010 but differed in 2009 where $100 \% \mathrm{P}$ application registered significantly higher. PE was 16.5 and $9.8 \%$ higher on 100 and $75 \% \mathrm{~K}$, respectively over $50 \% \mathrm{~K}$. Similarly, with P levels, PE was 14.4 and $3.4 \%$ higher on 100 and $75 \% \mathrm{P}$, respectively over $50 \% \mathrm{P}$. In both the years $\mathrm{P}$ application with $100 \%$ gave significantly higher PE. This might be due to better growth and yield attributes and finally leads to higher yield. The applied nutrients were efficiently taken up by plants. Similar finding was also reported by Singh et al. (2010).

\section{Nitrogen uptake and balance}

The $\mathrm{N}$ uptake significantly $(\mathrm{P}<0.05)$ differed with the different levels of $\mathrm{K}$ and $\mathrm{P}$ which clearly indicates that the $\mathrm{N}$ uptake was highest with the application of $100 \%$ $\mathrm{K}$ in both the years. However, lowest $\mathrm{N}$ uptake was recorded with $50 \% \mathrm{~K}$ (Table 3 ). Increased $\mathrm{N}$ uptake due to higher yield was also confirmed by Tanwar et al. (2010). The nitrogen budgeting was greatly influenced by the levels of $\mathrm{K}$ and $\mathrm{P}$ applied. It can be visualized that among the $\mathrm{K}$ levels, $100 \%$ of applied $\mathrm{K}$ recorded $71.3 \%$ higher actual gain of $\mathrm{N}$ followed by $75 \%(39.3 \%)$. However, the balance was recorded $92.6 \%$ higher in $100 \% \mathrm{~K}$ followed by $46.3 \%$ with $75 \%$ of $\mathrm{K}$ over the $50 \%$ of K. It 
clearly indicates that the application of higher levels of $\mathrm{K}$ helped the plant to synthesis more $\mathrm{N}$ than the lower level of $\mathrm{K}$.

Among the P levels, higher $\mathrm{N}$ uptake was recorded with $100 \% \mathrm{P}$ followed by $75 \%$ P than $50 \%$ P. Similarly, actual N gain was $110.6 \%$ higher with $100 \%$ followed by $75 \%(55.8 \%$ higher) over the $50 \% \mathrm{P}$. This also clearly depicts that as $\mathrm{P}$ levels increased the $\mathrm{N}$ fixation significantly increased and more $\mathrm{N}$ was left over in the soil. During 2009 the $\mathrm{N}$ fixation and actual gain of $\mathrm{N}$ was comparatively higher than 2010 which might be due to higher rainfall during 2010 (Figure 1). The high rainfall during the crop period might restrict the plants to fix $\mathrm{N}$ in lower quantities or created unfavourable condition might have leached some of the fixed $\mathrm{N}$.

\section{Phosphorus uptake and balance}

Uptake of $\mathrm{P}$ varied significantly $(\mathrm{P}<0.05)$ with $\mathrm{K}$ and $\mathrm{P}$ levels. Among the $\mathrm{K}$ levels, the higher $\mathrm{P}$ was taken up when crop was applied with $100 \% \mathrm{~K}$ followed by $75 \% \mathrm{~K}$ during both the years (Table 4). However, the least $\mathrm{P}$ uptake was recorded with $50 \% \mathrm{~K}$ application. This might be due to the applied $\mathrm{P}$ was fixed by the Fe- and Al-oxides in the soils (Sample et al., 1980). But still, as K levels increased from 50 to $100 \%$ the actual $\mathrm{P}$ gain was recorded 25 and $10 \%$ higher in 100 and $75 \% \mathrm{~K}$, respectively. Similarly, as P balance increased from 50 to $100 \% \mathrm{~K}$ levels increased by 14.9 and $6.8 \%$ in 100 and $75 \% \mathrm{P}$, respectively.

Among the $\mathrm{P}$ levels, uptake of $\mathrm{P}$ was higher with $100 \% \mathrm{P}$ followed by $75 \% \mathrm{P}$ during both the years. $\mathrm{P}$ balance increased with 60.7 and $32.9 \%$ in 100 and $75 \% \mathrm{P}$ over $50 \% \mathrm{P}$. On the other hand, least $\mathrm{P}$ uptake was recorded with $50 \%$ of $\mathrm{P}$ application. The present study also indicated that plant roots were able to induce transformation and uptake of non-labile soil-P within the soil volume exploited by roots and root hairs. Plants facing a withdrawal of inorganic $\mathrm{P}$ can adapt their physiology and development in order to efficiently use the lower supply of $\mathrm{P}$ (Thierry, 2008).

\section{Potassium uptake and balance}

Uptake of $\mathrm{K}$ varied significantly $(\mathrm{P}<0.05)$ with $\mathrm{K}$ and $\mathrm{P}$ levels. Among the $\mathrm{K}$ levels, the higher $\mathrm{K}$ was taken up when crop was supplied with $100 \% \mathrm{~K}$ followed by $75 \% \mathrm{~K}$ (Table 5). However, the least uptake was recorded with $50 \% \mathrm{~K}$ application. The $\mathrm{K}$ balance is greatly influenced by the applied $\mathrm{K}$ and $\mathrm{P}$ levels. The actual gain was recorded higher as $\mathrm{K}$ levels increased in order of $100 \%>75 \%>50 \%$. However, $\mathrm{K}$ balance was recorded $81.8 \%$ higher with $100 \% \mathrm{~K}$ followed by $75 \%(43.8 \%$ higher).

Among the $\mathrm{P}$ levels, uptake of $\mathrm{K}$ was higher on $100 \% \mathrm{P}$ followed by $75 \% \mathrm{P}$ during both the years. As $\mathrm{P}$ levels increased the balance of $\mathrm{K}$ also increased significantly in order of $100 \%>75 \%>50 \%$. However, it was recorded that $100 \% \mathrm{P}$ level increased the $\mathrm{K}$ balance with $25.7 \%$ followed by $14.7 \%$ in $75 \% \mathrm{P}$ over $50 \% \mathrm{P}$ application. This might be due to better uptake and efficient utilization of applied nutrients for producing growth and yield attributes and finally leads to higher yield. Similar finding was also reported by Pandey et al. (2006). The positive balance of K 
was observed due to release of $\mathrm{K}$ from its non exchangeable pool of the soil to meet the demand of crop.

There were significant and positive correlation between $\mathrm{N}$ and $\mathrm{P}$ uptake $\left(\mathrm{R}^{2}=\right.$ $0.791)$ and $\mathrm{K}$ uptake $\left(\mathrm{R}^{2}=0.722\right)$ (Figure 2 ). This clearly indicates that as $\mathrm{N}$ uptake increases, it augments the uptake of $\mathrm{P}$ and K. Similarly, NUE had the positive correlation with PUE $\left(\mathrm{R}^{2}=0.43\right)$ and followed the exponential relationship, whereas, NUE have the negative linear correlation with KUE $\left(\mathrm{R}^{2}=0.139\right)$ (Figure 3).

\section{Energetic analysis}

The energy output was higher for stover as compared to green pod because of higher production of stover. Energy input was higher in sequence $100 \%>75 \%>$ $50 \%$ for $\mathrm{K}$ and $\mathrm{P}$ levels (Table 6). This is due to more fertilizer input was involved in production. However, energy output was higher for $100 \% \mathrm{~K}$ followed by $75 \%$ and least by $50 \% \mathrm{~K}$. Energy of green pod was highest with higher levels of $\mathrm{K}$ and $\mathrm{P}$. This was due to highest green pod yield was obtained by supplying the higher levels of $\mathrm{K}$ and $\mathrm{P}$ which directly contributed to highest energy output. The Net energy and energy output: input ratio followed the similar trend to energy output. However, the energy output: input ratio ranged from 7.76 to 8.73 in 2009 and 7.08 to 8.78 during 2010 for the $\mathrm{K}$ levels and similar trend was noticed for P levels. The EP was $0.217 \mathrm{~kg}$ $\mathrm{MJ}^{-1}$ with $100 \% \mathrm{~K}$ followed by $0.202 \mathrm{~kg} \mathrm{MJ}^{-1}$ in $75 \% \mathrm{~K}^{2}$ and least with $0.181 \mathrm{~kg} \mathrm{MJ}^{-1}$ in $50 \% \mathrm{~K}$. Among the P levels EP were higher for $100 \% \mathrm{P}$ followed by $75 \% \mathrm{P}(0.219$ and $1.96 \mathrm{~kg} \mathrm{MJ}^{-1}$, respectively) and least with $50 \% \mathrm{P}\left(0.186 \mathrm{~kg} \mathrm{MJ}^{-1}\right)$. Similarly, energy use efficiency of green pod and stover were higher with 100\% K (146.9 and 829.4 , respectively) followed by $75 \%$ and least with $50 \% \mathrm{P}$. The energy productivity was $19.6 \%$ higher in $100 \% \mathrm{~K}$ followed by $11.6 \%$ in $75 \% \mathrm{~K}$ over $50 \% \mathrm{~K}$. Similarly with P levels EP was 17.5 and $5.1 \%$ higher for $100 \%$ and $75 \% \mathrm{P}$ over $50 \% \mathrm{P}$. On the other hand, energy use efficiency of green pod and stover was recorded 19.4 and $15.4 \%$ respectively higher in $100 \% \mathrm{~K}$ followed by 11.1 and $5.9 \%$ in $75 \% \mathrm{~K}$ (Table 7). Among the P levels, energy use efficiency of green pod and stover was 17.4 and $12.7 \%$ respectively higher with $100 \% \mathrm{~K}$ and 5.2 and $6.8 \%$ higher in $75 \%$ of $\mathrm{P}$ over $50 \%$ of $\mathrm{P}$. It is very much clear from the above findings that as the $\mathrm{K}$ and $\mathrm{P}$ levels increased the energy productivity and energy use efficiency of green pod and stover also increased. Similar findings were also reported by Ozkan et al. (2004) in cowpea and Padhi et al. (2010) in cereals and legumes.

\section{Economic analysis}

It is evident from the table 8 that the return and $\mathrm{B}$ : $\mathrm{C}$ ratio is greatly influenced by the levels of $\mathrm{K}$ and $\mathrm{P}$. Gross return, net return and BCR was significantly highest with $100 \% \mathrm{~K}$ application in 2009 but at par to 100 and $75 \% \mathrm{~K}$ application in 2010 . Similar trend was followed in case of $\mathrm{P}$ application but BCR was identical to all $\mathrm{P}$ doses. Among the K levels, the sequence of return and BCR followed $100 \%>75 \%>$ $50 \%$. Similar trend was recorded for P levels and highest with $100 \% \mathrm{P}$ followed by $75 \%$ and least by $50 \%$ P. During both the years the BCR followed the similar trend but all the three $\mathrm{P}$ and $\mathrm{K}$ levels did not significantly differ (Table 8). 
However, the interaction of $\mathrm{K}$ and $\mathrm{P}$ were statistically similar. It was found that cowpea had direct benefit of $\mathrm{N}_{2}$ - fixation and also increased the benefit of residual soil fertility. Application of higher level of $\mathrm{K}$ and $\mathrm{P}$ significantly increased the yield and also helped the budget of N, P and K. Higher level of K $\left(40 \mathrm{~kg} \mathrm{ha}^{-1}\right)$ and P $(60 \mathrm{~kg}$ $\mathrm{ha}^{-1}$ ) helped efficient production as well as utilization of energy and economic benefit.

\section{REFERENCES}

Abayomi, Y. A., Ajibade, T. V., Sammuel, O. F. and Saadudeen, B. F. 2008. Growth and yield responses of cowpea genotype to NPK application in the southern Guinea Savanna Zone of Nigeria. Asian Journal of Plant Sciences, 7(2): 170-176

Devasenapathy, P., Senthikumar, G. and Shanmugam, P. M. 2009. Energy management in crop production. Indian Journal of Agronomy, 54(1): 80-90

Khan, D. F., Peoples, M. B., Chalk, P. M. and Herridge, D. F. 2002. Quantifying belowground nitrogen of legumes. 2. A comparison of ${ }^{15} \mathrm{~N}$ and non-isotopic methods. Plant Soil, 239: 277-289

Mpepereki, S., Javaheri, F., Davis, P. and Giller, K. E. 2000. Soyabeans and sustainable agriculture: 'promiscuous' soyabeans in Southern Africa. Field Crops Research, 65: 137-149

Neumann, E. and George, E. 2009. The effect of arbuscular mycorrhizal root colonization on growth and nutrient uptake of two different cowpea genotypes exposed to drought stress. Emeritus Journal of Food and Agriculture, 21(2): 1-17

Ozkan, B., Akcaoz, H. and Fert, C. 2004. Energy input-output analysis in Turkish agriculture. Renewable Energy, 29: 39-51

Padhi, A. K., Jena, B. K. and Panigrahi, R. K. 2010. Performance of double cropping systems involving legume vegetables and finger millet under rainfed condition. Indian Journal of Agricultural Research, 44(1): 14-19

Panday, N., Verma, A. K., Anurag and Tripathi, R. S. 2006. Integrated nutrient management in transplanted rice. Indian Journal of Agronomy, 52(1): 40-42

Sample, E. C., Soper, R. J. and Racz, G. J. 1980. Reactions of phosphate fertilizers in soils. In: The role of phosphorus in agriculture. Eds. Khasawneh, F. E. Sample, E. C. and Kamprath, E. J. pp. 263-310. ASA, CSSA, SSSA. Madison, WI

Schlecht, E., Buerkert, A., Tielkes, E. and Bationo, A. 2006. A critical analysis of challenges and opportunities for soil fertility restoration in Sudano-Sahelian West Africa. Nutrient Cycling in Agro ecosystems, 76: 109-136

Singh, P., Singh, P., Singh, K. N., Singh, R., Aga, F. A., Bahar, F. and Raja, W. 2010. Evaluation of wheat genotypes for productivity and economics under graded levels of nitrogen in temperate Kashmir. Indian Journal of Agricultural Sciences, 80(5): 380384

Tanwar, S. P. S., Rokadia, P. and Singh, A. K. 2010. Productivity, nutrient balance and economics of kabuli chickpea as influenced by integrated nutrient management. Indian Journal of Agronomy, 55(1): 51-55

Thierry, D. 2008. Root branching responses to phosphate and nitrate. Current Opinion Plant Biology, 11: 82-87

Vance, C. P. 2001. Symbiotic nitrogen fixation and phosphorus acquisition. plant nutrition in a world of declining renewable resources. Plant Physiology, 127: 390-397 
Table 2: Dry matter accumulation, pod and stover yield and production efficiency as influenced by potassium and phosphorus

\begin{tabular}{|c|c|c|c|c|c|c|c|c|}
\hline \multirow[t]{2}{*}{ Treatment } & \multicolumn{2}{|c|}{$\begin{array}{l}\text { Total dry matter } \\
\quad\left(\text { g plant }^{-1}\right)\end{array}$} & \multicolumn{2}{|c|}{$\begin{array}{l}\text { Green pod yield } \\
\qquad\left(\mathrm{t} \mathrm{ha}^{-1}\right)\end{array}$} & \multicolumn{2}{|c|}{$\begin{array}{l}\text { Stover yield } \\
\left(\mathrm{t} \mathrm{ha}^{-1}\right)\end{array}$} & \multicolumn{2}{|c|}{$\begin{array}{c}\text { Production } \\
\text { efficiency (kg ha } \\
\left.\text { day }^{-1}\right)\end{array}$} \\
\hline & 2009 & 2010 & 2009 & 2010 & 2009 & 2010 & 2009 & 2010 \\
\hline \multicolumn{9}{|l|}{ Potassium } \\
\hline $100 \%$ & $26.33^{\mathrm{a}}$ & $23.87^{\mathrm{a}}$ & $4.23^{\mathrm{a}}$ & $4.01^{\mathrm{a}}$ & $12.43^{\mathrm{a}}$ & $12.82^{\mathrm{a}}$ & $49.97^{\mathrm{a}}$ & $47.30^{\mathrm{a}}$ \\
\hline $75 \%$ & $23.33^{\mathrm{b}}$ & $22.50^{\mathrm{b}}$ & $3.77^{\mathrm{b}}$ & $3.86^{\mathrm{a}}$ & $11.64^{b}$ & $11.38^{\mathrm{b}}$ & $45.31^{b}$ & $46.40^{\mathrm{a}}$ \\
\hline $50 \%$ & $21.00^{\mathrm{c}}$ & $21.44^{\mathrm{c}}$ & $3.52^{\mathrm{b}}$ & $3.30^{\mathrm{b}}$ & $11.16^{\mathrm{b}}$ & $10.46^{\mathrm{c}}$ & $43.09^{b}$ & $40.38^{\mathrm{b}}$ \\
\hline $\begin{array}{l}\text { LSD } \\
(\mathrm{P}=0.05)\end{array}$ & 1.71 & 0.95 & 0.34 & 0.24 & 0.69 & 0.87 & 4.01 & 2.88 \\
\hline \multicolumn{9}{|l|}{ Phosphorus } \\
\hline $100 \%$ & $27.67^{\mathrm{a}}$ & $24.11^{\mathrm{a}}$ & $4.23^{\mathrm{a}}$ & $4.12^{\mathrm{a}}$ & $12.41^{\mathrm{a}}$ & $12.53^{\mathrm{a}}$ & $49.76^{\mathrm{a}}$ & $48.33^{\mathrm{a}}$ \\
\hline $75 \%$ & $23.00^{\mathrm{b}}$ & $22.31^{\mathrm{b}}$ & $3.76^{\mathrm{b}}$ & $3.64^{\mathrm{b}}$ & $11.70^{\mathrm{ab}}$ & $11.64^{\mathrm{ab}}$ & $45.02^{\mathrm{b}}$ & $43.61^{\mathrm{b}}$ \\
\hline $50 \%$ & $20.00^{c}$ & $21.39^{\mathrm{b}}$ & $3.53^{\mathrm{b}}$ & $3.42^{\mathrm{b}}$ & $11.13^{\mathrm{b}}$ & $10.48^{\mathrm{b}}$ & $43.59^{\mathrm{b}}$ & $42.14^{b}$ \\
\hline $\begin{array}{l}\text { LSD } \\
(\mathrm{P}=0.05)\end{array}$ & 2.72 & 1.39 & 0.40 & 0.40 & 0.85 & 1.29 & 4.25 & 4.27 \\
\hline
\end{tabular}

K levels: $100 \%$ (40 kg); 75\% (30 kg) and 50\% (20 kg);

P levels: $100 \%$ (60 kg); 75\% (45 kg) and 50\% (30 kg);

Values with the same letter within each variables group are not significantly different $(P<0.05)$ 
Table 3: Balance sheet of $\mathbf{N}\left(\mathrm{kg} \mathrm{ha}^{-1}\right)$ as influenced by potassium and phosphorus management in cowpea

\begin{tabular}{|c|c|c|c|c|c|c|c|c|c|c|c|c|c|c|}
\hline \multirow[t]{2}{*}{ Treatment } & \multicolumn{2}{|c|}{$\begin{array}{c}\text { Initial soil N } \\
\text { status (a) }\end{array}$} & \multicolumn{2}{|c|}{$\mathrm{N}$ added (b) } & \multicolumn{2}{|c|}{$\begin{array}{c}\text { N uptake by crop } \\
\text { (c) }\end{array}$} & \multicolumn{2}{|c|}{$\begin{array}{l}\text { Soil N status after } \\
\text { crop harvest (d) }\end{array}$} & \multicolumn{2}{|c|}{$\begin{array}{c}\text { Nitrogen } \\
\text { fixation }[(\mathbf{c}+\mathbf{d})- \\
(\mathbf{a}+\mathbf{b})] \\
\end{array}$} & \multicolumn{2}{|c|}{$\begin{array}{c}\text { Actual gain/ loss } \\
\text { over initial } \\
\text { status (a-d) } \\
\end{array}$} & \multicolumn{2}{|c|}{$\begin{array}{c}\mathrm{N} \text { balance }[(\mathbf{a}+\mathbf{b})- \\
(\mathbf{c}+\mathbf{d})]\end{array}$} \\
\hline & 2009 & 2010 & 2009 & 2010 & 2009 & 2010 & 2009 & 2010 & 2009 & 2010 & 2009 & 2010 & 2009 & 2010 \\
\hline $100 \%$ & 205.6 & 239.1 & 50.0 & 50.0 & $71.53^{\mathrm{a}}$ & $68.78^{\mathrm{a}}$ & 239.1 & 268.77 & 55.03 & 48.45 & -33.5 & -29.67 & -55.03 & -48.45 \\
\hline $75 \%$ & 205.6 & 231.9 & 50.0 & 50.0 & $64.67^{\mathrm{b}}$ & $62.67^{\mathrm{b}}$ & 231.9 & 256.97 & 40.97 & 37.65 & -26.3 & -25.07 & -40.97 & -37.65 \\
\hline $50 \%$ & 205.6 & 224.6 & 50.0 & 50.0 & $58.97^{c}$ & $56.89^{c}$ & 224.6 & 243.47 & 27.97 & 25.76 & -19.0 & -17.87 & -27.97 & -25.76 \\
\hline $100 \%$ & 205.6 & 242.7 & 50.0 & 50.0 & $72.89^{a}$ & $70.00^{\mathrm{a}}$ & 242.7 & 274.9 & 59.99 & 52.20 & -37.1 & -32.20 & -59.99 & -52.20 \\
\hline $75 \%$ & 205.6 & 232.3 & 50.0 & 50.0 & $64.14^{\mathrm{b}}$ & $62.11^{\mathrm{b}}$ & 232.3 & 256.87 & 40.86 & 36.68 & -26.7 & -24.57 & -40.86 & -36.68 \\
\hline $50 \%$ & 205.6 & 221.1 & 50.0 & 50.0 & $58.13^{c}$ & $56.22^{\mathrm{b}}$ & 221.1 & 238.51 & 23.63 & 21.56 & -15.5 & -17.41 & -23.63 & -21.56 \\
\hline $\operatorname{LSD}(\mathrm{P}=0.05$ & NS & NS & NS & NS & 5.97 & 6.76 & NS & NS & NS & NS & NS & NS & NS & NS \\
\hline
\end{tabular}

Values with the same letter within each variables group are not significantly different $(P<0.05)$

Table 4: Balance sheet of $P\left(\mathrm{~kg} \mathrm{ha}^{-1}\right)$ as influenced by potassium and phosphorus management in cowpea

\begin{tabular}{|c|c|c|c|c|c|c|c|c|c|c|c|c|}
\hline \multirow[t]{2}{*}{ Treatment } & \multicolumn{2}{|c|}{$\begin{array}{c}\text { Initial soil P } \\
\text { status (a) }\end{array}$} & \multicolumn{2}{|c|}{$P$ added (b) } & \multicolumn{2}{|c|}{ P uptake by crop (c) } & \multicolumn{2}{|c|}{$\begin{array}{l}\text { Soil P status after } \\
\text { crop harvest (d) }\end{array}$} & \multicolumn{2}{|c|}{$\begin{array}{c}\text { Actual gain/ loss } \\
\text { over initial status } \\
\text { (a-d) }\end{array}$} & \multicolumn{2}{|c|}{$\begin{array}{c}\text { P balance }(a+b)- \\
(c+d)\end{array}$} \\
\hline & 2009 & 2010 & 2009 & 2010 & 2009 & 2010 & 2009 & 2010 & 2009 & 2010 & 2009 & 2010 \\
\hline \multicolumn{13}{|l|}{ Potassium } \\
\hline $75 \%$ & 8.3 & 9.7 & 55.0 & 55.0 & $12.69^{b}$ & $11.87^{\mathrm{b}}$ & 9.7 & 10.5 & -1.4 & -0.8 & 40.91 & 42.33 \\
\hline $50 \%$ & 8.3 & 9.7 & 55.0 & 55.0 & $10.02^{c}$ & $9.10^{c}$ & 9.7 & 10.3 & -1.4 & -0.6 & 43.58 & 45.30 \\
\hline LSD $(\mathrm{P}=0.05$ & NS & NS & NS & NS & 1.30 & 1.02 & NS & NS & & & & \\
\hline \multicolumn{13}{|l|}{ Phosphorus } \\
\hline $50 \%$ & 8.3 & 8.1 & 40 & 40 & $8.76^{c}$ & $7.79^{\mathrm{c}}$ & 8.1 & 8.4 & 0.2 & -0.3 & 31.44 & 31.91 \\
\hline $\operatorname{LSD}(\mathrm{P}=0.05)$ & NS & NS & NS & NS & 2.62 & 2.38 & NS & NS & & & & \\
\hline
\end{tabular}

Values with the same letter within each variables group are not significantly different $(P<0.05)$ 
Table 5: Balance sheet of $\mathrm{K}\left(\mathrm{kg} \mathrm{ha}^{-1}\right)$ as influenced by potassium and phosphorus management in cowpea

\begin{tabular}{|c|c|c|c|c|c|c|c|c|c|c|c|c|}
\hline \multirow[t]{2}{*}{ Treatment } & \multicolumn{2}{|c|}{$\begin{array}{l}\text { Initial soil K } \\
\text { status (a) }\end{array}$} & \multicolumn{2}{|c|}{$\mathrm{K}$ added (b) } & \multicolumn{2}{|c|}{$\begin{array}{c}\text { K uptake by crop } \\
\text { (c) }\end{array}$} & \multicolumn{2}{|c|}{$\begin{array}{l}\text { Soil K status } \\
\text { after crop } \\
\text { harvest (d) }\end{array}$} & \multicolumn{2}{|c|}{$\begin{array}{l}\text { Actual gain/ } \\
\text { loss over initial } \\
\text { status (a-d) }\end{array}$} & \multicolumn{2}{|c|}{$\begin{array}{c}\text { K balance } \\
(\mathbf{a}+\mathbf{b})-(\mathbf{c}+\mathbf{d})\end{array}$} \\
\hline & 2009 & 2010 & 2009 & 2010 & 2009 & 2010 & 2009 & 2010 & 2009 & 2010 & 2009 & 2010 \\
\hline \multicolumn{13}{|l|}{ Potassium } \\
\hline $100 \%$ & 260.0 & 310.8 & 65 & 65 & $86.19^{\mathrm{a}}$ & $84.89^{\mathrm{a}}$ & 310.8 & 352.9 & -50.8 & -42.1 & -72.0 & -62.0 \\
\hline $75 \%$ & 260.0 & 293.7 & 55 & 55 & $81.34^{\mathrm{b}}$ & $78.89^{\mathrm{a}}$ & 293.7 & 315.8 & -33.7 & -22.1 & -60.0 & -46.0 \\
\hline $50 \%$ & 260.0 & 272.8 & 45 & 45 & $74.16^{\mathrm{c}}$ & $71.89^{\mathrm{b}}$ & 272.8 & 276.9 & -12.8 & -4.1 & -42.7 & -31.0 \\
\hline LSD $(P=0.05$ & NS & NS & NS & NS & 2.79 & 6.48 & NS & NS & & & & \\
\hline \multicolumn{13}{|l|}{ Phosphorus } \\
\hline $100 \%$ & 260.0 & 292.5 & 55.0 & 55.0 & $85.61^{\mathrm{a}}$ & $84.56^{\mathrm{a}}$ & 292.5 & 315.4 & -32.5 & -22.9 & -63.1 & -52.5 \\
\hline $75 \%$ & 260.0 & 292.4 & 55.0 & 55.0 & $81.36^{\mathrm{a}}$ & $78.89^{\mathrm{ab}}$ & 292.4 & 315.2 & -32.4 & -22.8 & -58.8 & -46.7 \\
\hline $50 \%$ & 260.0 & 292.2 & 55.0 & 55.0 & $74.72^{\mathrm{b}}$ & $72.22^{\mathrm{b}}$ & 292.2 & 315.1 & -32.2 & -22.7 & -51.9 & -40.1 \\
\hline $\operatorname{LSD}(\mathrm{P}=0.05)$ & NS & NS & NS & NS & 5.59 & 7.15 & NS & NS & & & & \\
\hline
\end{tabular}

Values with the same letter within each variables group are not significantly different $(P<0.05)$

Table 6: Energetic parameters (MJ ha ${ }^{-1}$ ) as influenced by potassium and phosphorus management in cowpea

\begin{tabular}{|c|c|c|c|c|c|c|c|c|c|c|c|c|}
\hline \multirow{2}{*}{ Treatment } & \multicolumn{2}{|c|}{ Energy output (pod) } & \multicolumn{2}{|c|}{ Energy output (stover) } & \multicolumn{2}{|c|}{ Total energy output } & \multicolumn{2}{|c|}{ Energy input } & \multicolumn{2}{|c|}{ Net energy } & \multicolumn{2}{|c|}{ Output: input } \\
\hline & 2009 & 2010 & 2009 & 2010 & 2009 & 2010 & 2009 & 2010 & 2009 & 2010 & 2009 & 2010 \\
\hline $100 \%$ & $28702^{\mathrm{a}}$ & $27195.3^{\mathrm{a}}$ & $155417^{\mathrm{a}}$ & $160278^{\mathrm{a}}$ & $184119^{\mathrm{a}}$ & $187430^{\mathrm{a}}$ & 18896 & 19146 & $165223^{\mathrm{a}}$ & $168327^{\mathrm{a}}$ & $8.73^{\mathrm{a}}$ & $8.78^{\mathrm{a}}$ \\
\hline $50 \%$ & $23881^{\mathrm{b}}$ & $22374.0^{\mathrm{b}}$ & $139583^{b}$ & $130694^{\mathrm{c}}$ & $163464^{\mathrm{c}}$ & $153068^{\mathrm{c}}$ & 18671 & 18921 & $144793^{c}$ & $134148^{\mathrm{c}}$ & $7.76^{\mathrm{b}}$ & $7.08^{\mathrm{c}}$ \\
\hline LSD (0.05) & 2307.7 & 1641.8 & 8637.3 & 10852 & 7365.4 & 11616 & & & 7365.4 & 11616 & 0.387 & 0.59 \\
\hline $75 \%$ & $25463^{b}$ & $24649^{b}$ & $146250^{\mathrm{ab}}$ & $145556^{\mathrm{ab}}$ & $171713^{\mathrm{b}}$ & $170205^{\mathrm{ab}}$ & 18772.4 & 19022.4 & $152940^{\mathrm{b}}$ & $151182^{\mathrm{ab}}$ & $8.14^{\mathrm{ab}}$ & $7.92^{\mathrm{at}}$ \\
\hline $50 \%$ & $23956^{\mathrm{b}}$ & $23157^{\mathrm{b}}$ & $139167^{\mathrm{b}}$ & A30972 & $163123^{b}$ & $154130^{\mathrm{b}}$ & 18558.2 & 18808.2 & $144564^{b}$ & $135321^{\mathrm{b}}$ & $7.80^{\mathrm{b}}$ & $7.20^{\mathrm{b}}$ \\
\hline LSD (0.05) & 2687 & 2719.1 & 10634 & 16141 & 11563 & 17914 & & & 11491 & 17837 & 0.57 & 0.90 \\
\hline
\end{tabular}

Values with the same letter within each variables group are not significantly different $(P<0.05)$ 
Table7: Energy productivity and use efficiency as influenced by potassium and phosphorus management in cowpea

\begin{tabular}{|c|c|c|c|c|c|c|}
\hline \multirow{2}{*}{ Treatment } & \multicolumn{2}{|c|}{$\begin{array}{c}\text { Energy } \\
\text { productivity }\end{array}$} & \multicolumn{2}{|c|}{$\begin{array}{c}\text { Energy use } \\
\text { efficiency (pod) }\end{array}$} & \multicolumn{2}{|c|}{$\begin{array}{c}\text { Energy use } \\
\text { efficiency (stover) }\end{array}$} \\
\hline & 2009 & 2010 & 2009 & 2010 & 2009 & 2010 \\
\hline \multicolumn{7}{|l|}{ Potassium } \\
\hline $100 \%$ & $0.224^{\mathrm{a}}$ & $0.209^{\mathrm{a}}$ & $151.83^{\mathrm{a}}$ & $141.92^{\mathrm{a}}$ & $822.31^{\mathrm{a}}$ & $836.54^{\mathrm{a}}$ \\
\hline $75 \%$ & $0.201^{\mathrm{b}}$ & $0.203^{\mathrm{a}}$ & $136.00^{\mathrm{b}}$ & $137.41^{\mathrm{a}}$ & $775.51^{b}$ & $747.61^{b}$ \\
\hline $50 \%$ & $0.188^{b}$ & $0.174^{\mathrm{b}}$ & $127.81^{b}$ & $118.20^{\mathrm{b}}$ & $747.29^{b}$ & $690.47^{\mathrm{c}}$ \\
\hline $\operatorname{LSD}(0.05)$ & 0.018 & 0.013 & 12.20 & 8.59 & 45.49 & 56.94 \\
\hline \multicolumn{7}{|l|}{ Phosphorus } \\
\hline $100 \%$ & $0.223^{\mathrm{a}}$ & $0.214^{\mathrm{a}}$ & $151.02^{\mathrm{a}}$ & $144.88^{\mathrm{a}}$ & $816.48^{\mathrm{a}}$ & $813.58^{\mathrm{a}}$ \\
\hline $75 \%$ & $0.200^{\mathrm{b}}$ & $0.191^{\mathrm{b}}$ & $135.58^{\mathrm{b}}$ & $129.57^{\mathrm{b}}$ & $778.94^{\mathrm{ab}}$ & $764.84^{\mathrm{ab}}$ \\
\hline $50 \%$ & $0.190^{\mathrm{b}}$ & $0.182^{b}$ & $129.03^{\mathrm{b}}$ & $123.09^{\mathrm{b}}$ & $749.69^{b}$ & $696.20^{\mathrm{b}}$ \\
\hline $\operatorname{LSD}(0.05)$ & 0.020 & 0.020 & 13.75 & 13.75 & 53.85 & 81.59 \\
\hline
\end{tabular}

Values with the same letter within each variables group are not significantly different $(P<0.05)$

Table 8: Economic parameters $\left(₹ \mathrm{ha}^{-1}\right)$ as influenced by potassium and phosphorus management in cowpea

\begin{tabular}{|c|c|c|c|c|c|c|c|c|}
\hline \multirow{2}{*}{ Treatment } & \multicolumn{2}{|c|}{$\begin{array}{c}\text { Cost of } \\
\text { cultivation }\end{array}$} & \multicolumn{2}{|c|}{ Gross return } & \multicolumn{2}{|c|}{ Net return } & \multicolumn{2}{|c|}{ B:C } \\
\hline & 2009 & 2010 & 2009 & 2010 & 2009 & 2010 & 2009 & 2010 \\
\hline \multicolumn{9}{|l|}{ Potassium } \\
\hline $100 \%$ & 13500 & 13756 & $40083^{\mathrm{a}}$ & $38500.0^{\mathrm{a}}$ & $26583^{\mathrm{a}}$ & $24743.7^{\mathrm{a}}$ & $1.97^{\mathrm{a}}$ & $1.79^{\mathrm{a}}$ \\
\hline $75 \%$ & 13067 & 13306 & $35946^{\mathrm{b}}$ & $36533.3^{\mathrm{a}}$ & $22889^{b}$ & $23227.7^{\mathrm{a}}$ & $1.75^{\mathrm{b}}$ & $1.74^{\mathrm{a}}$ \\
\hline $50 \%$ & 12700 & 12955 & $33761^{\mathrm{b}}$ & $31627.8^{b}$ & $21061^{b}$ & $18672.1^{\mathrm{b}}$ & $1.66^{\mathrm{b}}$ & $1.44^{\mathrm{b}}$ \\
\hline $\operatorname{LSD}(0.05)$ & & & 2514.3 & 2150.4 & 2514.3 & 2150.4 & 0.186 & 0.157 \\
\hline \multicolumn{9}{|l|}{ Phosphorus } \\
\hline $100 \%$ & 14067 & 14308 & $40072^{\mathrm{a}}$ & $39191^{\mathrm{a}}$ & $26006^{\mathrm{a}}$ & $24883^{\mathrm{a}}$ & $1.85^{\mathrm{a}}$ & $1.73^{\mathrm{a}}$ \\
\hline $75 \%$ & 13067 & 13305 & $35894^{\mathrm{b}}$ & $34907^{\mathrm{b}}$ & $22828^{\mathrm{b}}$ & $21602^{\mathrm{ab}}$ & $1.78^{\mathrm{a}}$ & $1.62^{\mathrm{a}}$ \\
\hline $50 \%$ & 12133 & 12404 & $33833^{b}$ & $32563^{b}$ & $21700^{\mathrm{b}}$ & $20159^{b}$ & $1.74^{\mathrm{a}}$ & $1.62^{\mathrm{a}}$ \\
\hline $\operatorname{LSD}(0.05)$ & & & 3296.4 & 3634.8 & 3026.4 & 3362.1 & 0.198 & 0.215 \\
\hline
\end{tabular}

Values with the same letter within each variables group are not significantly different $(\mathrm{P}<0.05)$ 


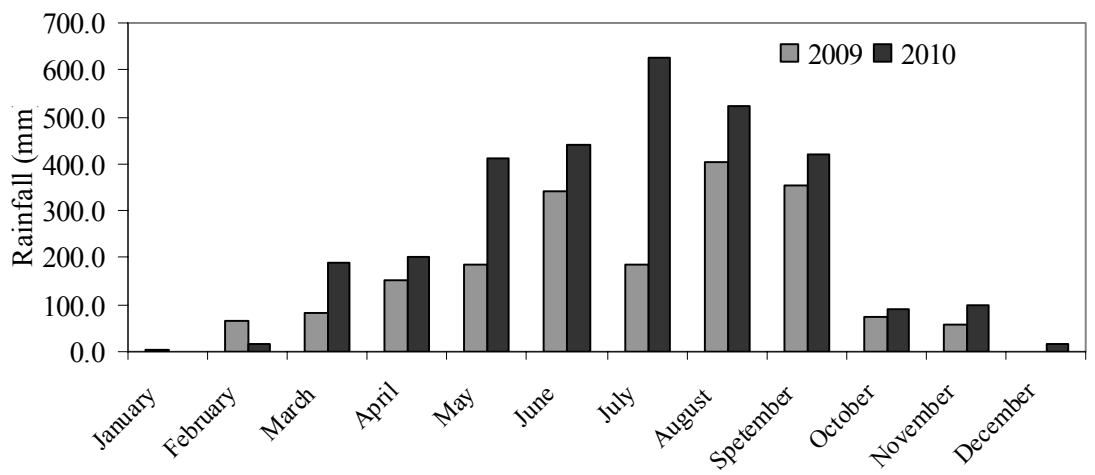

Figure 1: Rainfall distribution of the experimental site during 2009 and 2010

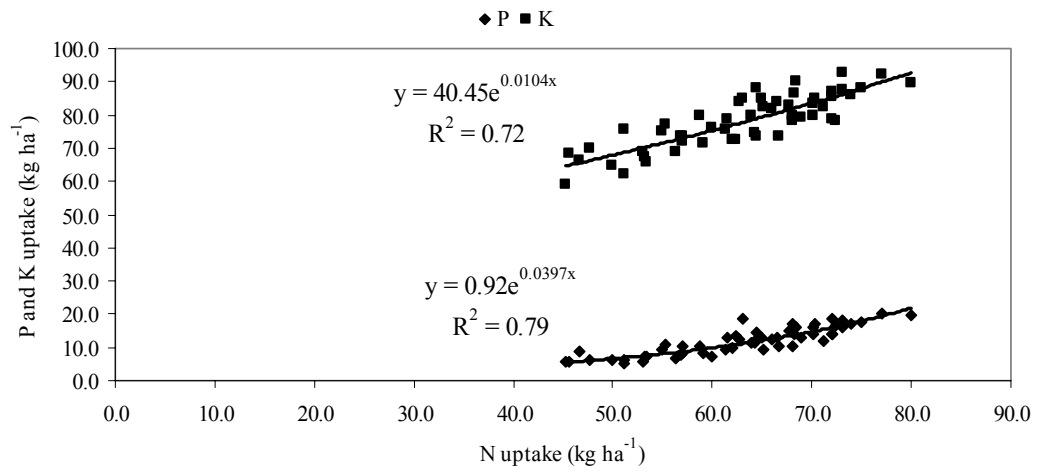

Figure 2: Relationship between nitrogen uptake $\left(\mathrm{kg} \mathrm{ha}^{-1}\right)$ with phosphorus in $\mathrm{kg} \mathrm{ha}^{-1}(\bullet \mathrm{P}=$ $\left.40.45 \mathrm{e}^{0.0104 \mathrm{x}} \mathrm{R}^{2}=0.72\right)$ and potassium uptake in $\mathrm{kg} \mathrm{ha}^{-1}\left(\bullet \mathrm{K} \mathrm{y}=0.92 \mathrm{e}^{0.0397 \mathrm{x}}, \mathrm{R}^{2}=0.79\right)$

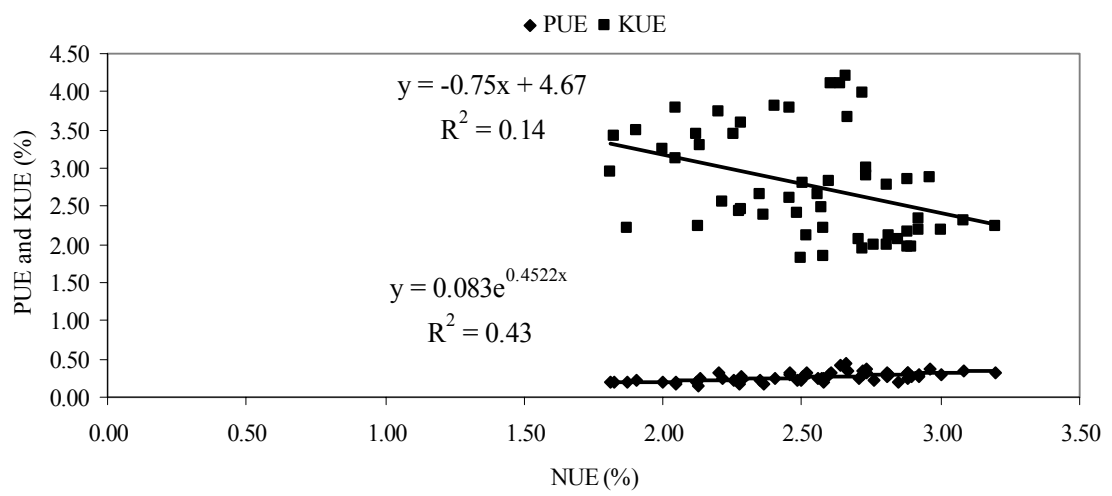

Figure 3: Relationship between nitrogen use efficiency (\%) with phosphorus use efficiency $\left(\bullet\right.$ PUE $\left.y=0.083 \mathrm{e}^{0.4522 \mathrm{x}} \mathrm{R}^{2}=0.72\right)$ and potassium use efficiency $(\bullet$ KUE $\mathrm{y}=$ $-0.75 \mathrm{x}+4.67, \mathrm{R}^{2}=0.14$ ) 